\title{
Eturauhassyöpäpotilaiden ja heidän puolisoidensa terveyteen liittyvä elämänlaatu ja parisuhde
}

Suomen Syöpäyhdistyksen julkaisemana Syöpä-lehti järjesti vuonna 2017 kirjoituskilpailun nimeltään "Syöpä läheisen tai ystävän silmin". Kilpailun voitti haminalainen harrastajakirjailija rouva Arja Makkonen, jonka kirjoituksesta "Kolmen ässän talo" luen seuraavat katkelmat.

"Tie tähän päivään alkoi vuonna 2010. Työterveydessä seurattiin kevään aikana mieheni kohonneita PSA-arvoja, kunnes tuli lähete urologille. Kesäkuun alussa otettiin koepalat. Urologi oli soittanut heti juhannuksen jälkeen miehelleni töihin ja kertonut, että syöpä löytyi. Jo pelkkä sana SYÖPÄ, oli karmeudessaan vailla vertaa. Silmissä vilisivät kaikki mahdolliset asiat, ja päällimmäisenä oli ajatus, että miten tästä selviydytään. Entä kaikki tulevaisuuden suunnitelmat, tulevien eläkepäivien harrastukset, omakotitalon työt ja muut ybteiset asiat. Entä se seuraava etappi, 40-vuotishääpäivä.

Kun mies tuli tiedonsaamispäivänä töistä kotiin, asiasta ei saatu ensin minkäänlaista keskustelua aikaiseksi. Luulen, että kumpikin luki netistä kaiken mitä eturauhassyövästä kerrottiin. Muutaman päivän jälkeen syövästä alettiin pubua. Sauna se on suomalaiselle sellainen paikka, joka kirvoittaa kielen kannat. Itkettiin, mietittiin ja juteltiin.
Miespuolisella benkilöllä oli tietenkin myös mielessä, jos eturauhanen joudutaan poistamaan, miten käy mieskunnolle. Siihen totesin, että tämä liitto ei siihen lopu, jos/kun sillä saralla biljenee, muistellaan, vaikka menneitä jos niin käy. Oli myös vaikea kertoa eturauhassyövästä lapsille. Heillä oli jo omat elämät, mutta kävivät usein kotona "vanhuksia katsomassa", kuten he asian ilmaisivat. Tytär pelästyi kovin, poikakin, mutta lakoniseen tapaansa kysyi: "eihän ukko vaan kuole?" Parhaamme lobduteltiin. Tuntui jotenkin kummalta, me lohduttelimme lapsia, vaikka mieshän siinä sairas oli. Kävimme yhdessä urologin vastaanotolla ja helpotus oli melkoinen, kun hän kertoi, että kyseessä on ns. "kiltti eturauhassyöpä”. Urologi kertoi eri hoitomuodoista ja tuntui oudolta, kun hoitomuoto piti itse valita. Toki tutkittiin myös, ettei etäpesäkkeitä ole. Siinä vaiheessa uskalsi jo hieman hengähtää.

Loppukesästä ennen hoitoa teimme serkkuni ja hänen rouvansa kanssa tanssireissun Krouvin lavalle. Otettiin porukalla vähän kuohujuomaa ja mies kertoi heille sairastavansa eturauhassyöpää. Ensin porukalla pikkasen itkeä pirauteltiin ja serkun rouva sairaanhoitajana kertoi faktoja hoidoista. Hän kertoi myös molempien veljien- sä sairastaneen samaa mörköä jo useampia vuosia. Silloin alkoi tuntua, että eiköhän tästä selvitä. Oli helpottavaa, kun sairaudesta pystyi pubumaan ulkopuoliselle. Oli ikään kuin lopullisesti myöntänyt sairauden olemassaolon.

Syöpä hoidettiin marraskuussa 2010. Mies kertoi, kun meni taksilla sairaalaan, että taksinkuljettaja oli kysynyt, onko sinulla syöpä, kun menet sille ovelle? Mitäpä tuoda kieltämään, ja taksinkuljettaja oli kertonut oman tarinansa sädeboidoista eturauhassyöpäänsä. Oli kuulemma tullut tunne, että en ole yksin tämän kanssa tappelemassa. Hoito tehtiin, ja kaikki meni hyvin. Kävimme eturauhassyöpää sairastavien parisuhdekurssin. Se oli byvä kurssi. Sieltä sai paljon asiatietoa, vertaistukea sekä voimia selviytyä eteenpäin. Onhan hoidosta jäänyt joitakin jälkivaivoja, vessassa mies saa juosta varsin liukkaasti etenkin aamuisin, myös katetroinnissa joutui aikoinaan käymään, mutta pääasiallisesti tällä hetkellä kaikki on hyvin. Nuo vaivat ovat todellakin pieni hinta siitä, että syöpä on hoidettu."

Tämä tosielämän kuvaus eturauhassyövästä puolison silmin johdattaa meitä tänään tarkastettavan väitöstutkimuksen aihepiiriin. Eturauhassyöpä on 
miesten yleisin syöpä Suomessa ja teollistuneissa länsimaissa. Suomessa eturauhassyöpään sairastuu vuosittain lähes 5000 miestä. Syöpärekisterin tilastojen mukaan yhä useampi mies paranee syövästä ja yhtenä tulevaisuuden haasteena on varmistaa syövästä selvinneiden elämänlaatu. Mitä elämänlaatu sitten tarkoittaa? Ja miksi sitä on tarpeen mitata?

Terveyteen liittyvä elämänlaatu on keskeinen hoidon laadun mittari ja keskeinen terveystutkimuksen kohde. Hoitotieteen päämääränä on ihmisen kokonaisuuden huomioiva hoitaminen. Hoitotieteen yksi tärkeä käsite ja tutkimuskohde on terveys, joka tällä hetkellä hoitotieteessä määritellään henkilökohtaisena voimavarana tai kykynä ja se yhdistetään elämänlaatuun ja hyvinvointiin. (Eriksson ym. 2012). Koettu elämänlaatu on käsitteenä läheisesti yhteydessä hyvinvointiin, eikä elämänlaadulle löydy yhteneväistä teoreettista määritelmää. Vaaraman (2008) mukaan koettu elämänlaatu on dynaaminen ja moniulotteinen prosessi, jossa ovat vuorovaikutuksessa keskenään yksilölliset, yhteisölliset, yhteiskunnalliset ja kulttuuriset tekijät. Terveyteen liittyvä elämänlaatu voidaan määritellä myös henkilökohtaiseksi hyvänolontunteeksi tai onnellisuudeksi, joka on seurausta tyytyväisyydestä tai tyytymättömyydestä elämänalueisiin, joita pitää itselle tärkeänä (Ferrens 1990, Pietilä 2010).

Yhdistyneiden kansakuntien teettämässä World Happiness Report 2018 -raportissa Suomi sijoittui kärkisijalle 156 maan joukossa. Kyseisen tutkimuksen mukaan me suomalaiset olem- me maailman onnellisin kansa. Tosi asia on, että Pohjoismaat sijoittuvat tämän kaltaisissa vertailuissa korkealle. Hyvinvointiin ja onnellisuuteen liittyy ihmisen arvomaailma. Suomalaisen arvotutkijan Klaus Helkaman (2015) mukaan niillä ihmisillä, joiden arvot ovat muiden saman ryhmän jäsenten, kuten esimerkiksi perheen, koululuokan tai kansakunnan, arvojen kanssa samankaltaisia, on tutkitusti vähemmän stressioireita. Ihminen voi siis hyvin silloin, kun hänen arvonsa ovat sopusoinnussa hänen ympäristönsä arvojen kanssa.

Eturauhassyöpä liittyy olennaisesti ikääntymiseen, taudin esiintyvyys nousee nopeasti lähes 70 prosenttiin 60-69-vuotiailla miehillä. Sairauden kaksijakoisuutta kuvaa sanonta "jotkut miehet kuolevat eturauhassyöpään, mutta kaikilla kuolleilla miehillä on eturauhassyöpä”. (Ablin 2016.) Eturauhassyöpä todetaan harvoin oireiden tai kliinisten löydösten perusteella. Diagnooseista suurimman osan taustalla on koholla oleva PSA eli prostata spesifinen antigeeni arvo, joka testataan verikokeella. Kun patologi Richard J. Ablin kehitti vuonna 1970 PSA-testin hän korosti, ettei PSA ole syöpäspesifinen testaus. Hän havainnollistaa testin ongelmallisuutta seuraavasti. "Kuvittele jänis ja kilpikonna avoimeen laatikkoon, joka vastaa eturauhasta. Kilpikonna etenee hitaasti, eikä sen hidas ja loputon matka johda minnekään, eikä syöpä näin ollen johda kuolemaan. Jänis sen sijaan kuvaa ennustamatonta ja aggressiivista syöpää, joka jäniksen tavoin hyppii ulos laatikosta ja juokse ympäriinsä.
Näin tapabtuu, kun eturauhasen kuoren ulkopuolelle leviävät syöpäsolut muodostavat etäpesäkeitä eri puolille kehoa."

PSA-testin ongelmana ovat juuri nämä "kilpikonnat" eli väärät positiiviset. Näitä ovat löytyneet syövät, jotka ovat edellisen kuvauksen mukaisesti merkittävästi pienempiä ja kiltimpiä kuin aggressiivinen eturauhassyöpä. Eturauhassyövän hoitojen haitat virtsanpidätyskyvyttömyys, impotenssi ja psyykkiset traumat tulevat nopeasti, mutta mahdolliset hoitojen hyödyt vasta vuosien jälkeen. Osa eturauhassyövistä sen sijaan etenee hoidoista huolimatta tai osa syövistä on jo toteamishetkellä levinnyt eturauhasen ulkopuolelle johtaen oireiseen tautiin tai potilaan menehtymiseen. Eturauhassyövän diagnostiikkaa ja hoitoja kehitetään ja haittoja pyritään minimoimaan. Tämän vuoksi on ensiarvoisen tärkeää tunnistaa ja tutkia eturauhassyövän ja sen hoitojen vaikutukset potilaiden ja myös heidän puolisoidensa elämänlaatuun.

Kun perheessä yksi perheenjäsen sairastuu eturauhassyöpään, huomio tuskin kiinnittyy pelkästään syövän diagnosointiin tai hoitoon. Kuten rouva Arja Makkosen kirjoituksesta kuulimme, perheen sisällä tapahtuu muutoksia vallinneissa rooleissa, huolenpito tehtävissä ja perheenjäsenten välisissä siteissä. Hoitotiede ja ennen kaikkea perhehoitotiede on kiinnostunut erityisesti potilaan ja hänen läheistensä näkökulmasta erilaisissa hoitamisen konteksteissa. Professori Päivi Åstedt-Kurjen (2008) mukaan perhe ja parisuhde ovat voimavara, josta saamme voimaa ar- 
kielämän haasteisiin. Kuitenkin perheenjäsenen, kuten puolison sairastuminen esimerkiksi syöpään voi muuttaa perheen arkielämän raskaaksi ja parisuhde voi kriisiytyä.

Perheitä tutkittaessa huomio kiinnittyy usein lapsiperheisiin sekä vanhempien ja lasten väliseen hoivasuhteeseen. Perhe kulkee kuitenkin mukana läpi elämän. Perhe ei ole pysyvä ja kiinteä kokoonpano vaan perheeseen kuuluvat ihmiset vaihtelevat elämänkulun mukana. Myös vanhoilla ihmisillä on perhe ja perhetutkimusta tarvitaan selvittämään mitä muutoksia pidentynyt vanhuusikä ja erilaiset sairaudet, kuten esimerkiksi eturauhassyöpä aiheuttavat perheille ja perheen sisäisille suhteille. Parhaillaan Tampereella järjestettävillä Perhetutkimuksen päivillä teemana onneksi on "Elämänkulku ja sukupolvet". Tänään tarkistettavassa väitöskirjatutkimuksessa perhettä tarkastellaan parisuhteen näkökulmasta.

Parisuhde perustuu kahden ihmisen väliseen kiintymykseen ja seksuaalisuuteen. Hoitotieteen ja sosiologian näkökulmasta parisuhde rakentuu rakastumisesta, kiintymyksestä ja henkilökohtaisesta sitoutumisesta. Eri sukupolvien käsitys parisuhteesta on erilainen. Suomessa elettiin vielä pitkälle 1960-luvulle saakka varsin maatalousvaltaisessa yhteiskunnassa, jossa perhe oli yhteiskunnan perusyksikkö. Laaja perheyhteisö takasi riittävän työvoiman ja huolenpidon. Parisuhde ja rakkauselämä ovat muuttuneet vuosikymmenien aikana. Sodanjälkeisten suurten ikäluokkien käsitys parisuhteesta perustui paljolti aikuisuuden ja yhteis- kuntakelpoisuuden saavuttamiseen ja toteuttamiseen. Entistä suurempi ja kokonaisvaltaisempi yksilöllisyys alkoi kuitenkin määritellä nuorten ihmisten elämää noin 1980-luvulta alkaen teollistuneissa länsimaissa. Avioliitto ei ole enää elintason kohennettua välttämätön mahdollistamaan kohtuullista kulutustasoa, vaan erilaiset elämäntavat ovat mahdollisia ja varsin tasavertaisia entistä iäkkäimmillä ihmisillä. (Saarinen 2017.)

Yksilöllisyyden korostumisesta huolimatta parisuhde ei ole menettänyt merkitystään, vaan siihen panostetaan edelleen. Erotuksena aiemmista sukupolvista nykyisin keskitytään itse suhteeseen. Avioliitto tai parisuhde ei ole väline joidenkin muiden päämäärien mahdollistamiseksi. Yhteiseltä parisuhteelta odotetaan läheisyyttä, emotionaalisten tarpeiden tyydyttämistä ja parisuhteessa saa aiempaa suuremman merkityksen tunteet, hellyys ja seksuaalinen nautinto. Eturauhassyövän hoitoihin liittyvistä haittavaikutuksista suurin osa liittyy juuri seksuaalisuuteen sekä virtsatieoireisiin. Nämä haitat pahimmassa tapauksessa invalidisoivat potilasta psyykkisesti ja sosiaalisesti sekä ovat kiusallisia ja vaikeuttavat normaalia elämää ja parisuhdetta.

Onko terveydenhuollon ammattilaisten tarpeellista puuttua näihin perheen ja parisuhteen sisäisiin haasteisiin? Ja jos on, niin miten? Rouva Arja Makkonen kirjoitti, että "Oli helpottavaa, kun sairaudesta pystyi puhumaan ulkopuoliselle". Sairaanhoitajien koulutussäätiön julkaisemassa Sairaanhoidon vuosikirjassa vuodelta 1958 eli 60 vuotta sitten Aila Pohjanpää raportoi Helsingin kaupungin sairaalassa toteutetun kyselytutkimuksen "Sairaalan vierastunnit" tuloksia seuraavasti: "Vierastuntien tärkeyttä potilaan hoidossa ei ilmeisesti sairaaloissa ole täysin otettu huomioon, koska on yleisenä tapana, ettei osastolla vierastunnin aikana ole henkilökuntaa kuin minimimäärä. Vierastunnin aikana tulisi henkilökunnan, etupäässä hoidosta vastaavien sairaanhoitajien, tavata osastolle tulevat vieraat ja keskustella heidän kanssaan. Tällöin olisi myös omaisilla tilaisuus saada tietoja potilaan voinnista. Osaston henkilökuntavahvuuksia määrättäessä ja työvnoroja järjestettäessä tämä seikka olisi otettava buomioon.”

Mikä sairaalassa ja hoitotyössä on muuttunut Aila Pohjanpään 60 vuoden takaisesta tutkimusraportista? Enää emme puhu vierastunneista ja useammassa terveydenhuollon yksikössä perheenjäsenet ja läheiset voivat tavata hoidossa olevaa perheenjäsentä vapaasti. Aila Pohjanpää kuitenkin korosti jo 60 vuotta sitten, että sairaanhoitajien tulisi keskustella potilaiden läheisten kanssa ja tämä on huomioitava hänen mukaansa myös työvuorosuunnittelussa. Hoitotyössä hoitajien taito yhteistyöhön ja tutkimustiedon hyödyntämiseen ovat yhteydessä siihen, kuinka potilaiden ja heidän perheenjäsentensä tuen tarpeet tulevat tunnistetuksi sairaalahoidon aikana. Hoitotyöntutkimussäätiön ja Sairaanhoitajaliiton vuonna 2017 tekemän kyselyn perusteella kaksi kolmasosaa kyselyyn vastanneesta 1400 sairaanhoitajasta oli sitä mieltä, että hoitokäytännöt eivät perustu tutkimustietoon, 
eivätkä viimeisimpiin hoitosuosituksiin. Tutkitun tiedon soveltamisessa hoitotyöhön on siis sairaanhoitajien itsensä mielestä haasteita. Tänään tarkastettavan väitöskirjan yhtenä keskeisenä johtopäätöksenä on, että eturauhassyöpäpotilaiden puolisot tulisi huomioida ja heitä tulisi kannustaa osallistumaan potilaan hoitoon koko hoitoprosessin ajan. Mielestäni tämä tarkoittaa muun muassa juuri tuota Aila Pohjanpään suositusta siitä, että sairaalassa tulisi henkilökunnan, etupäässä hoidosta vastaavien sairaanhoitajien, tavata osastolle tulevat puolisot ja keskustella heidän kanssaan.

\section{KIRJALLISUUTTA:}

Ablin RL, Piana R. Suuri eturauhashuijaus: miten suuri lääketeollisuus kaappasi PSA-testin ja aiheutti julkisen terveydenhuollon katastrofin. Pietiläinen K (suom) Helsinki: Terra Cognita, Liblis Oy; 2016.

Eriksson K, Isola A, Kyngäs H, Leino-Kilpi H, Lindström U.Å, Paavilainen E, Salanterä S, Vehviläinen-Julkunen K, ÅstedtKurki P. Hoitotiede. 4. uud. p. Helsinki: Sanoma Pro; 2012.

Ferrans C.E. Quality of life: Conceptual issues. Seminars in Oncology Nursing 1990;6:248254. https:/doi.org/10.1016/07492081(90)90026-2

Helkama K. Suomalaisten arvot. Helsinki: Suomalaisen kirjallisuuden seura; 2015.
Pietilä A. Terveyden edistäminen: teorioista toimintaan. Helsinki: WSOYpro Oy; 2010.

Saarinen R. Oppi luottamuksesta. Tallinna: Gaudeamus Oy; 2017.

Vaarama M, Pieper R, Sixsmith A. Care-related Quality of Life in Old Age: Concepts, Models and Empirical Findings. New York: Springer; 2008.

Åstedt-Kurki P. Kohti perheen hyvää hoitamista. Porvoo: WSOY Oppimateriaalit; 2008.

Eeva Harju

$T t T$, sh

Tampereen yliopisto

Yhteiskuntatieteiden tiedekunta, Terveystieteet, Hoitotiede 